J. Amer. Soc. Hort. ScI. 120(1):54-58. 1995.

\title{
Effect of Potassium, Magnesium, and Calcium Deficiencies on Carbohydrate Pools and Metabolism in Citrus Leaves
}

\author{
Ruth Lavon \\ Institute of Horticulture, Agricultural Research Organization, The Volcani Center, Bet Dagan, \\ Israel 50250 \\ Eliezer E. Goldschmidt \\ The Kennedy-Leigh Centre for Horticultural Research, Faculty of Agriculture, The Hebrew University \\ of Jerusalem, Rehovot, Israel 71600 \\ Rafael Salomon and Andre Frank \\ Institute of Plant Protection, Agricultural Research Organization, The Volcani Center, Bet Dagan, \\ Israel 50250
}

Additional index words. acid invertase, $\beta$ - amylase, soluble sugar, starch, sucrose, Citrus volkameriana, Citrus retilculata
(austera $\mathrm{x}$ fortunella $\mathrm{spp}$.), Citrus sinensis 'Shamouti'

\begin{abstract}
Carbohydrate content and related enzyme activities were determined in leaves of rough-lemon (Citrus volkameriana Ten. \& Pasq) plants grown under $\mathrm{K}$, Mg, and Ca deficiencies. Starch content was lower and soluble sugar significantly higher in K-deficient than in control leaves. Magnesium- and Ca-deficient leaves, on the other hand, accumulated large amounts of starch. Electron micrographs also showed a reduction in the number and size of starch grains in chloroplasts of $\mathrm{K}$-deficient leaves, while those of $\mathrm{Mg}$ - and Ca-deficient leaves were filled with large starch grains. Total amylase activity increased 3- to 7-fold in K-deficient leaves, with maltose as the major product and small amounts of maltotriose. Electrophoretic separation of amylase isozymes on native gels containing starch or amylopectin showed higher band intensities in K-deficient leaves. Examination of the capacity of leaf extracts to use amylopectin vs. $\beta$ - limit dextrin indicated that mainly 8-amylase was involved. Acid invertase activity increased 7-fold in K-deficient leaves, while alkaline invertase showed little change.
\end{abstract}

In most higher plants, the principal end-products of leaf photosynthesis are starch and sucrose. However, species partition the photosynthate differently between starch and sucrose, and various factors affect this partitioning pattern (Huber, 1989). Starch is the major storage carbohydate in Citrus (Sanz and Guardiola, 1988) and may comprise as much as $12.3 \%$ of leaf dry matter (Goldschmidt and Golomb, 1982).

The links between mineral deficiencies and carbohydrate metabolism are complex and poorly understood. Potassium deficiency resulted in increased soluble sugar accumulation in leaves of tomato (Wall, 1939) and wheat (Ward, 1960). Huber (1984) found that K-deficient soybean leaves contained less starch and higher hexose and sucrose as well as increased acid invertase activity. Accumulation of starch grains has been observed in chloroplasts of $\mathrm{Mg}$ - and $\mathrm{Ca}$-deficient tomato and spinach plants (Vesk et al., 1966). Starch and sucrose accumulation has recently been described also in Mg-deficient Phaseolus vuglaris leaves (Fischer and Bremer, 1993).

In the present study we investigated the effects of $\mathrm{K}, \mathrm{Mg}$, and Ca deficiences in Citrus on leaf carbohydrate pools. The results prompted a subsequent examination of some closely related enzyme systems. While the present study centered on rough lemon (Citrus volkameriana), supplementary data were obtained from experiments with calamondin [Citrus reticulata (austera $\mathrm{x}$ fortunella spp.)] and 'Shamouti' orange (Citrus sinensis L. Osbeck).

Received for publication 1 Feb. 1994. Accepted for publication 29 July 1994. Contribution of the Agricultural Research Organization, The Volcani Center, Bet Dagan, Israel. We gratefully acknowledge the technical assistance of Esther Mohl, S. Shapchiski, and D. Galili. The cost of publishing this paper was defrayed in part by the payment of page charges. Under postal regulations, this paper therefore must be hereby marked advertisement solely to indicate this fact.

\section{Material and Methods}

Plant material and growth conditions. Rough-lemon cuttings were grown in aerated nutrient solutions. The solutions were modifications of those used in Long Ashton (Hewitt, 1966). Full nutrient solutions consisted of $1 \mathrm{mM} \mathrm{KNO}_{3}, 0.9 \mathrm{mM} \mathrm{MgSO} \cdot 7 \mathrm{H}_{2} \mathrm{O}$, $3.8 \mathrm{~mm} \mathrm{Ca}\left(\mathrm{NO}_{3}\right)_{2} \cdot 4 \mathrm{H}_{2} \mathrm{O}$, and $0.8 \mathrm{~mm} \mathrm{Na}_{2} \mathrm{HPO}_{4} \cdot 2 \mathrm{H}_{2} \mathrm{O}$. Iron was added as Fe-EDTA $\left(5.6 \mu \mathrm{g} \mathrm{Fe}{ }^{+3} / \mathrm{ml}\right)$. In $\mathrm{K}$-deficient solutions, $\mathrm{KNO}_{3}$ was replaced by $0.5 \mathrm{~mm} \mathrm{Mg}\left(\mathrm{NO}_{3}\right)_{2} \cdot 6 \mathrm{H}_{2} \mathrm{O}, 0.4 \mathrm{~mm}$ $\mathrm{Na}_{2} 3 \mathrm{HPO}_{4} \cdot 2 \mathrm{H}_{2} \mathrm{O}$, and $0.2\left(\mathrm{NH}_{4}\right)_{2} \mathrm{HPO}_{4}$. In $\mathrm{Mg}$-deficient solutions, $\mathrm{Mg}\left(\mathrm{NO}\right.$,), was replaced by $0.6 \mathrm{~mm} \mathrm{KNO}_{3}, 0.3 \mathrm{~mm} \mathrm{~K}_{2} \mathrm{SO}_{4}$, and 1.3 $\mathrm{mM} \mathrm{NaNO}_{3}$. In Ca-deficient solutions, $\mathrm{Ca}\left(\mathrm{NO}_{3}\right)_{2}$ was replaced by $1.9 \mathrm{~mm} \mathrm{Mg}\left(\mathrm{NO}_{3}\right)_{2} \cdot 6 \mathrm{H}_{2} \mathrm{O}$. All nutrient solutions included a complete complement of micronutrients (Hewitt, 1966). Calamondin seedlings were grown in sand cultures and fertigated with the same nutrient solutions. Plants were grown for 4 to 6 weeks in full nutrient solutions before transfer to deficient conditions. Plants were kept under deficient conditions at least 3 months until deficiency symptoms developed. Mature, fully expanded (2 to 3 months old) leaves with visible deficiency symptoms that had developed after the transfer to deficient conditions were used for the various analyses.

'Shamouti' orange leaves were collected from fruiting terminals of 30-year-old trees in a 5-year fertigation experiment; that experiment involves N-P-K, N-P, and N treatments in which the amounts of nutrients supplied are $220 \mathrm{~kg} \mathrm{~N}, 52 \mathrm{~kg} \mathrm{P}$, and $249 \mathrm{~kg} \mathrm{~K} /$ haper year.

Leaves were collected in the morning and rinsed in deionized water and the mid vein was removed.

Mineral analysis. Samples of leaf tissue were dried in a forcedair oven at 65C. Samples of $50 \mathrm{mg}$ ground leaf powder were extracted with $10 \mathrm{ml}$ deionized water according to Bar-Akiva 
(1974). After 30 min of shaking, K, Mg, and Ca were analyzed by atomic absorption spectroscopy.

Soluble sugar and starch determination. Six 7-mm-diameter discs from fresh leaves were extracted with $3 \mathrm{ml} 80 \%$ ethanol for $15 \mathrm{~min}$ at $80 \mathrm{C}$; the extraction was repeated five times. Supernatants were collected and brought to a volume of $15 \mathrm{ml}$. Soluble sugars were measured with anthrone (Schaffer et al., 1985). The insoluble leaf residue was boiled for $30 \mathrm{~min}$ with $1.0 \mathrm{ml} 0.2 \mathrm{M} \mathrm{KOH}$. Samples were cooled and adjusted to $\mathrm{pH} 4.5$ with $0.4 \mathrm{ml} 1.0 \mathrm{M}$ acetic acid. After amyloglucosidase treatment soluble sugar was measured with anthrone (Schaffer et al., 1985).

Amylase determination and starch hydrolysisproduct analysis. Leaf tissues were extracted with an Ultra-Turrax homogenizer in an extraction buffer containing $20 \mathrm{~mm}$ tris-maleate (pH 6.2), $5 \mathrm{~mm}$ $\mathrm{CaCl}_{2}$, and $0.04 \%$ Tween-20, using a 1 plant tissue : 10 buffer ratio. The extract was filtered through Miracloth and centrifuged at $40,000 \times g$ for $10 \mathrm{~min}$. Supernatants were dialysed overnight against the same buffer, from which Tween-20 was omitted, with two buffer changes and clarified by centrifugation at $40,000 \times g$ for $10 \mathrm{~min}$. The dialysate was used for total amylolytic enzyme assay according to a slightly modified version of Hammond and Burton (1983). All operations were carried out at 4C. Amylase activity was assayed in $1 \mathrm{ml}$ reaction mixtures containing $0.4 \%$ soluble potato starch solution improved by Lintner (Sigma), $2 \mathrm{~mm}$ acetate buffer ( $\mathrm{pH} \mathrm{5.3)}$ and $500 \mu \mathrm{l}$ of dialysate. The mixture was incubated for $45 \mathrm{~min}$ at $37 \mathrm{C}$. The reducing sugars released were determined according to Somogy (1952). Products of enzyme reactions were tentatively identified by paper chromatography according to Doehlert et al. (1982).

Gel electrophoresis of amylase isozymes. Leaf tissue was extracted according to Beers and Duke (1988) with the addition of $20 \%$ glycerol. The plant tissue-to-extraction-buffer ratio was 1: 10 . The extract was filtered through Miracloth and centrifuged at $1000 \times g$ for $10 \mathrm{~min}$. All operations were carried out at $4 \mathrm{C}$. Native gel electrophoresis was performed as described by Doehlert et al. (1982), except that $5 \%$ to $15 \%$ of linear-gradient polyacrylamide gels containing $0.2 \%$ soluble starch improved by Lintner (Sigma), $0.2 \%$ amylopectin, or $1.8 \% \beta$ - limit dextrin was used as substrates. Gels were stained with $2.5 \mathrm{mM} \mathrm{I}_{2}$ and $0.5 \mathrm{M} \mathrm{KI}$.

Invertase determination. Invertases were assayed according to Schaffer et al. (1987) with some modifications. Leaf tissue $(2.0 \mathrm{~g}$ fresh weight) was extracted in $10 \mathrm{ml}$ buffer containing $50 \mathrm{~mm}$ HEPES-NaOH ( $\mathrm{pH} 7.5$ ), $5 \mathrm{~mm} \mathrm{MgCl}_{2}, 1 \mathrm{~mm} \mathrm{Na}$ EDTA, and $0.05 \%$ Triton $\mathrm{X}-100$. The extract was passed through Miracloth and centrifuged at $17,300 \times g$ for $20 \mathrm{~min}$ at $4 \mathrm{C}$. The supernatant was concentrated by the addition of $\left(\mathrm{NH}_{4}\right)_{2} \mathrm{SO}_{4}$ to $80 \%$ saturation. After centrifugation for $15 \mathrm{~min}$ at $20,000 \times g$ the precipitate was resuspended in $2 \mathrm{ml}$ of extraction buffer and dialyzed overnight against 5 mM HEPES-NaOH (pH 7.5), $5 \mathrm{mM} \mathrm{MgCl}_{2}$, and $1 \mathrm{~mm} \mathrm{Na}_{2}$ EDTA. The invertase assay mixture contained $200 \mu$ dialyzed extract, 200 mM sucrose, and $100 \mathrm{~mm}$ citrate buffer $(\mathrm{pH}$ 5.0) for acid invertase and $100 \mathrm{~mm}$ HEPES-NaOH (pH 7.5) for alkaline invertase. The reaction mixtures were incubated for $45 \mathrm{~min}$ at $37 \mathrm{C}$ and the glucose and fructose released were determined with dinitrosalicylic acid.

Electron microscopy. Pieces of leaf tissue (about $1 \mathrm{~mm}$ square) were taken from the same leaves used for carbohydrate analyses. The pieces were fixed in $2 \%$ glutaraldehyde in $20 \mathrm{~mm}$ phosphate buffer ( $\mathrm{pH}$ 6.8) for $1 \mathrm{~h}$. Postfixation was done with $2 \%$ osmium tetroxide in $20 \mathrm{~mm}$ phosphate buffer ( $\mathrm{pH}$ 6.8), followed by dehydration in acetone and embedding in Agar- 100 (Orion and Frank, 1990). Sections were cut on an ultramicrotome (Ultratome III, LK13), stained with $2 \%$ uranyl acetate and lead citrate, and examined in an electron microscope (Jeol Gem 100 CX).

\section{Results}

In full nutrient solutions the concentrations of $\mathrm{K}, \mathrm{Mg}$, and $\mathrm{Ca}$ in leaves were in the optimum-high range (Embleton et al., 1973; Golomb, 1984). When grown in mineral-deficient solutions, tissue concentrations of these ions were significantly reduced (Table 1). Similar results were obtained with calamondin leaves (data not shown). In leaves from field-grown 'Shamouti' orange, K concentration was significantly lower in the N-P and N treatment than in the control leaves which had an optimal K concentration (data not shown).

The starch content of K-deficient rough-lemon leaves was lower, and that of $\mathrm{Mg}$ - and Ca-deficient leaves considerably higher than that of control leaves (Table 2). The concentration of soluble sugar was significantly higher in K-deficient than in control leaves (Table 2). The starch : sugar ratio was 0.4 for K-deficient leaves compared to 1.4 for control and 2.2 for $\mathrm{Mg}$ - and Ca-deficient leaves.

Decreased starch content of K-deficient leaves was also evident in electron micrographs (Fig. 1). Chloroplasts of K-deficient leaves were smaller and there were smaller and fewer starch grains. Chloroplasts of $\mathrm{Mg}$ - and $\mathrm{Ca}$-deficient leaves, on the other hand, were packed with oversized starch grains.

Total amylase activity was significantly higher in extracts from K-deficient leaves than in controls for rough lemon and calamondin (Table 3). In Mg- and Ca-deficient leaves, total amylase activity was not significantly higher than in controls. Results were essentially the same when expressed on a protein basis (data not shown).

Chromatographic analysis of the amylolytic reaction products revealed the presence of glucose and maltose. Rapid accumulation of maltose was evident in the K-deficient treatment (Fig. 2). An additional faint spot closer to the front was tentatively identified as maltotriose. Prolonged incubation $(20 \mathrm{~h})$ of control and K-deficient extracts with pullulan substrate yielded large amounts of maltotriose, indicating the presence of debranching enzyme activity (data not shown).

Electrophoretic separation of amylolytic extracts on polyacry-

Table 1. Concentration of $\mathrm{K}, \mathrm{Mg}$, and $\mathrm{Ca}$ in full-nutrient-control roughlemon leaves and in leaves from plants deficient in each respective element.

\begin{tabular}{lccc}
\hline \hline \multirow{2}{*}{$\begin{array}{l}\text { Nutritional } \\
\text { treatment }\end{array}$} & \multicolumn{3}{c}{$\begin{array}{c}\text { Elemental concn } \\
(\% \text { dry wt) }\end{array}$} \\
\cline { 2 - 4 } Control & $\mathrm{K}$ & $\mathrm{Mg}$ & $\mathrm{Ca}$ \\
Deficient & $0.77 \mathrm{a}^{z}$ & $0.31 \mathrm{a}$ & $0.35 \mathrm{a}$ \\
& $0.24 \mathrm{~b}$ & $0.03 \mathrm{~b}$ & $0.11 \mathrm{~b}$ \\
\hline
\end{tabular}

${ }^{\overline{2}}$ Mean separation within columns by Duncan's multiple range test at $P=0.05$.

Table 2. Starch, soluble sugar, and starch : soluble sugar ratio in roughlemon leaves deficient in $\mathrm{K}, \mathrm{Mg}$, and $\mathrm{Ca}$.

\begin{tabular}{lccc}
\hline & \multicolumn{3}{c}{$\begin{array}{c}\text { Foliar concn } \\
\left(\mathrm{mg} \cdot \mathrm{g}^{-1} \text { leaf fresh wt }\right)\end{array}$} \\
\cline { 2 - 4 } Treatment & Starch & Soluble & Starch : soluble \\
Sontrol & $37.2 \mathrm{ab}^{7}$ & $25.0 \mathrm{~b}$ & $1.4 \mathrm{ab}$ \\
K deficiency & $16.0 \mathrm{~b}$ & $38.3 \mathrm{a}$ & $0.4 \mathrm{~b}$ \\
Mg deficiency & $64.4 \mathrm{a}$ & $30.6 \mathrm{ab}$ & $2.2 \mathrm{a}$ \\
Ca deficiency & $65.6 \mathrm{a}$ & $31.0 \mathrm{ab}$ & $2.2 \mathrm{a}$ \\
\hline
\end{tabular}

${ }^{\overline{2} \text { Mean separation within columns by Duncan's multiple range test at } P=0.05 \text {. }}$ 


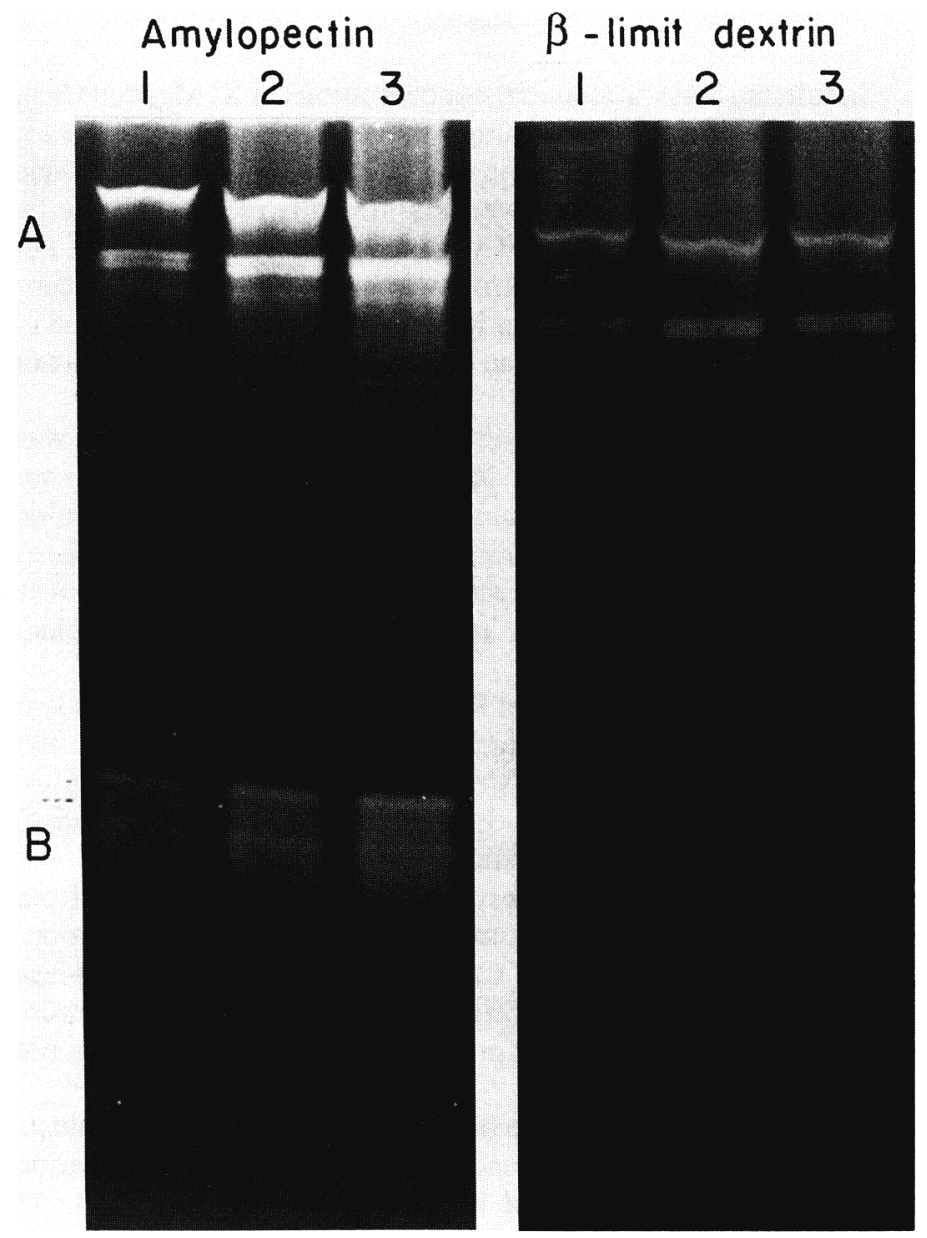

Fig. 1. Electron micrographs of chloroplasts from rough-lemon leaves from different nutritional treatments. (a) Control leaf, (b) K-deficient leaf, (c) Mgdeficient leaf, (d) Ca-deficient leaf; sg = starch gram.

Table 3. Total amylase activity in rough-lemon and calamondin leaves deficient in $\mathrm{K}, \mathrm{Mg}$, and $\mathrm{Ca}$.

\begin{tabular}{|c|c|c|}
\hline \multirow[b]{2}{*}{ Treatment } & \multicolumn{2}{|c|}{$\begin{array}{c}\text { Amylase activity } \\
\text { (mg reducing sugar/g fresh wt per } h \text { ) }\end{array}$} \\
\hline & Rough lemon & Calamondin \\
\hline Control & $2.1 \mathrm{~b}^{\mathrm{z}}$ & $1.9 \mathrm{~b}$ \\
\hline K deficiency. & $12.0 \mathrm{a}$ & $5.3 \mathrm{a}$ \\
\hline Mg deficiency & $3.7 \mathrm{~b}$ & $3.0 \mathrm{~b}$ \\
\hline Ca deficiency & $4.2 \mathrm{~b}$ & $2.2 \mathrm{~b}$ \\
\hline
\end{tabular}

${ }^{\bar{X}}$ Mean separation within columns by Duncan's multiple range test at $P=0.05$.

lamide gels containing starch or amylopectin as a substrate showed two groups of amylase isozymes: a slow (A) and a fast (B) migrating group (Figs. 3 and 4). Group B activity, which was rather weak in crude extracts, appeared clearly in $\left(\mathrm{NH}_{4}\right)_{2} \mathrm{SO}$, concentrated extracts (data not shown). With amylopectin as a substrate, group B stained red, whereas group A yielded bright, colorless bands (Fig. 4).

Group B activity did not appear on gels when $\beta$ - limit dextrin was used as a substrate in spite of the high amount of protein applied (Fig. 4). In both groups of isozymes, extracts from Kdeficient leaves had stronger amylase activity than controls with starch (Fig. 3) and amylopectin (Fig. 4). Group A isozymes digested P-limit dextrin, but no difference between K-deficient leaves and controls could be seen (Fig. 4).

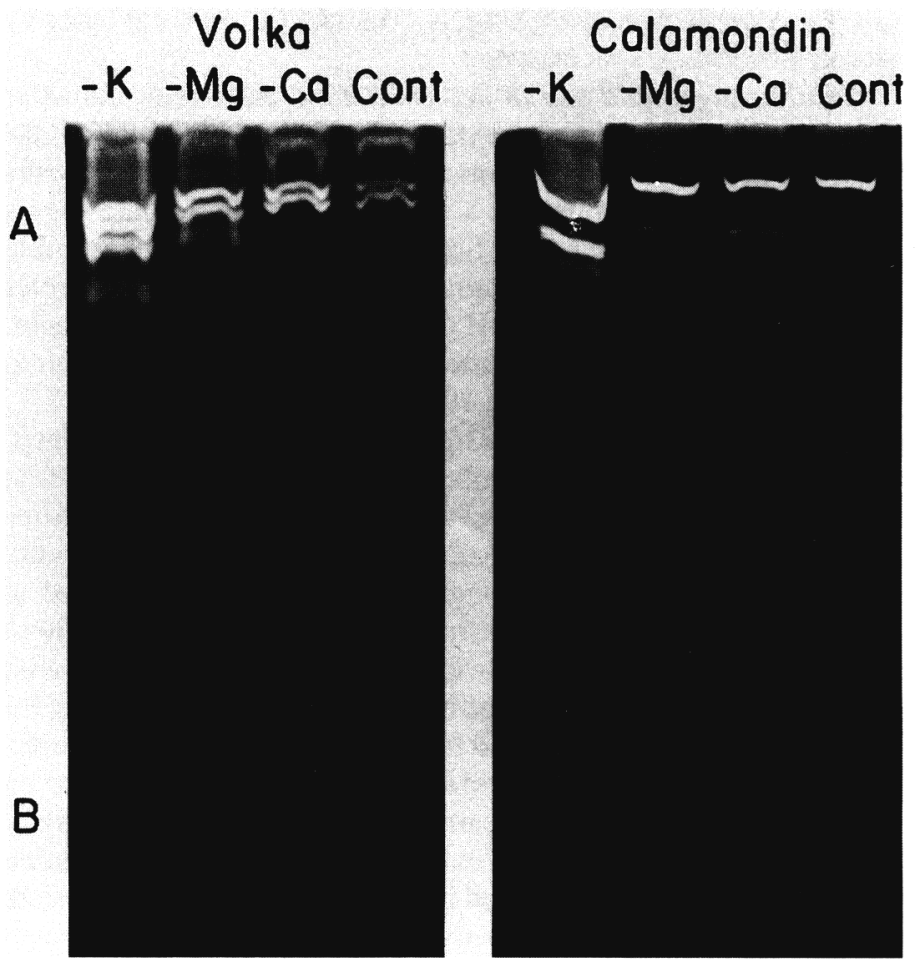

Fig. 2. Paper chromatogram of amylolytic reaction products by rough-lemon leaf extracts with $0.2 \%$ starch as a substrate. Extracts were incubated for $15 \mathrm{~min}$. Maltose (Mal) and glucose (G1c) markers (50 $\mu \mathrm{g}$ each) were used.

Acid invertase activity increased markedly in K-deficient leaf extracts compared to the control. In $\mathrm{Mg}$ - and $\mathrm{Ca}$-deficient leaf extracts acid invertase activity was low and undetectable, respectively (Table 4). Alkaline invertase activity was less affected by nutritional treatments (Table 4).

\section{Discussion}

This study reports effects of $\mathrm{K}, \mathrm{Mg}$, and $\mathrm{Ca}$ deficiencies on carbohydrate metabolism in Citrus leaves. Potassium deficiency produced the strongest effects, resulting in less starch and more soluble sugar. Magnesium and $\mathrm{Ca}$ deficiencies resulted in marked increase in starch content, demonstrated both chemically and microscopically. Potassium deficiency also resulted in higher amylase and acid invertase activities. A K-deficiency-related increase of acid invertase activity in soybean leaves has been described previously by Huber (1984); however, no effect on amylase has yet been reported.

Using different amylase substrates we attempted to characterize the changes in amylase isozyme activity. Whereas starch and amylopectin are digested by $\alpha$ - and $\beta$ - amylase, $\beta$ - limit dextrin is not digested by $\beta$ - amylase. When amylopectin is used as a substrate, $\beta$ - amylase activity produces red stain, while $\alpha$ - amylase produces white, colorless bands (Kakefuda and Duke, 1984; Kakefuda et al., 1986)

Group B isozyme activity was undetectable with $\beta$ - limit dextrin and produced red bands with amylopectin (Fig. 4), indicating that this group contained only $\beta$ - amylases. Group A, on the other hand, contained $\alpha$ - amylase as demonstrated by the colorless bands obtained with amylopectin and by the digestion of p-limit dextrin (Fig. 4). The much weaker digestion of $\beta$ - limit dextrin by group A, compared with amylopectin and starch, suggests that this group also contained $\beta$ - amylases. 
Table 4. Acid invertase and alkaline invertase activities in rough-lemon leaves deficient in $\mathrm{K}, \mathrm{Mg}$, and $\mathrm{Ca}$.

\begin{tabular}{lcc}
\hline \hline & \multicolumn{2}{c}{$\begin{array}{c}\text { Invertase activity } \\
\text { Treatment }\end{array}$} \\
\cline { 2 - 3 } (mg glucose equivalent/g fresh wt per $\mathrm{h}$ ) \\
\hline Control & Acid invertase & Alkaline invertase \\
K deficiency & $1.2 \mathrm{~b}^{\mathrm{z}}$ & $3.9 \mathrm{bc}$ \\
Mg deficiency & $8.5 \mathrm{a}$ & $5.5 \mathrm{a}$ \\
Ca deficiency & $0.2 \mathrm{~b}$ & $5.3 \mathrm{ab}$ \\
& $\mathrm{nd}^{\mathrm{y}}$ & $3.7 \mathrm{c}$ \\
\hline
\end{tabular}

${ }^{\overline{2}}$ Mean separation within columns by Duncan's multiple range test at $P=$ 0.05 .

yd $=$ Nondetectable.

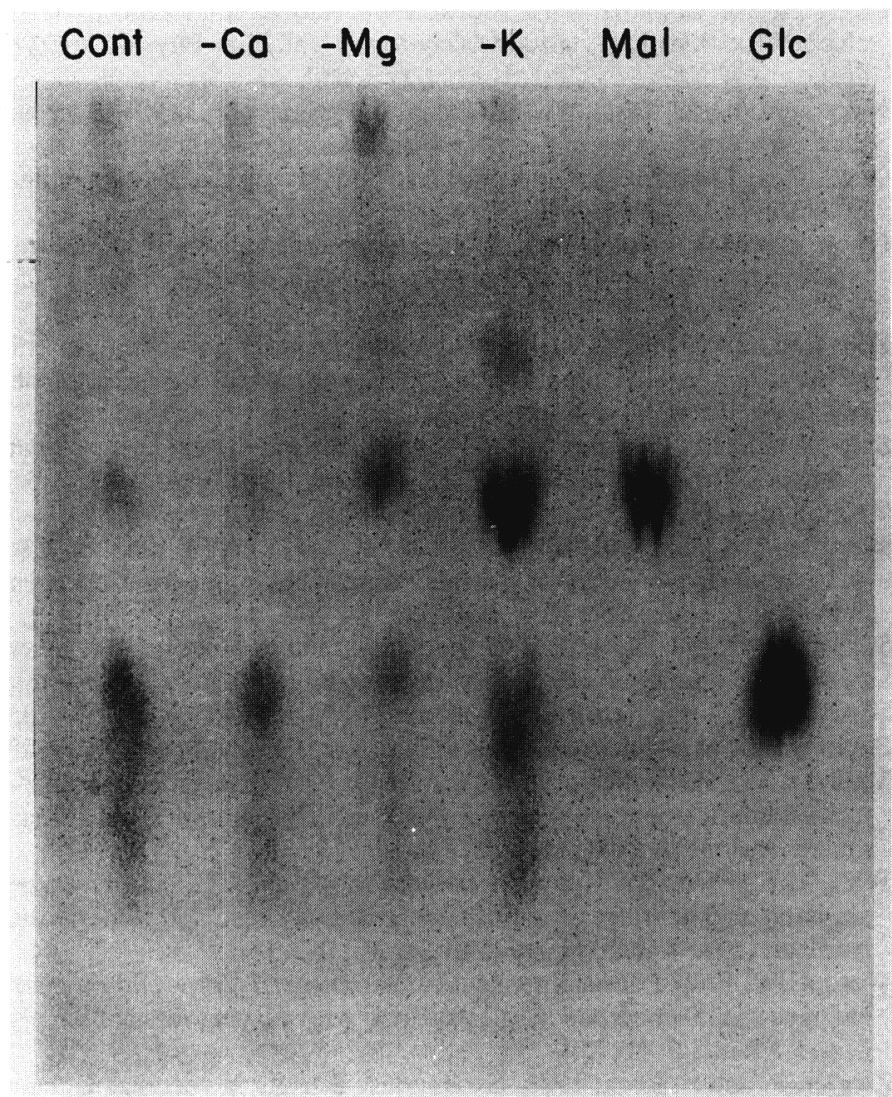

Fig 3. Amylase activity in rough-lemon and calamondin leaf extracts from different nutritional treatments. Crude extracts were separated on non-denaturating PAGE, containing Lintner soluble starch and stained with $\mathrm{KI}_{-} \mathrm{I}_{2}$. The amount of protein per lane was $2.5 \mu \mathrm{g}$.

Stronger activity of K-deficient extracts was evident in both isozyme groups (A and B) with starch (Fig. 3) and amylopectin (Fig. 4). These differences could not be observed with P-limit dextrin (Fig. 4). This indicates that the $\mathrm{K}$ deficiency induced mainly $\beta$ - amylase activity. The liberation of maltose as the major product of amylolytic activity in K-deficient leaf extracts (Fig. 2) also suggests a role for $\beta$ - amylase (Ziegler and Beck, 1986).

The results of the present study as a whole indicate that $\mathrm{K}$ deficiency interferes with carbohydrate status and metabolism of mature Citrus leaves. Apparently, under K deficiency, the starchsoluble-sugar balance changes in favor of the latter component. It is, however, impossible at this time to suggest a specific metabolic reaction and identify it as the source of the interference. Starch degradation is one likely area for further exploration, but this might
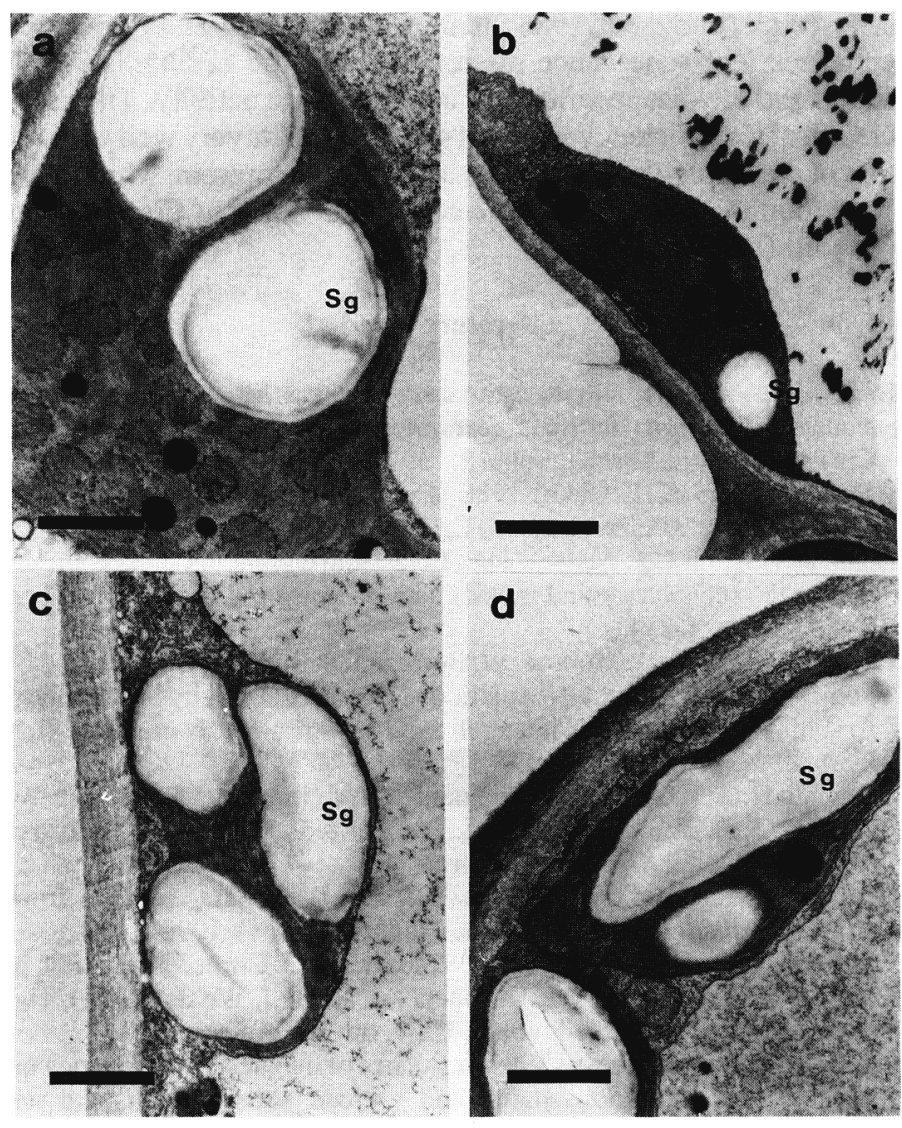

Fig. 4. Amylase activity in leaf extracts of 'Shamouti' orange from N-P-K (1) N$P$ (2) and N (3) fertilization treatments. Crude extracts were separated on nondenaturating PAGE containing either amylopectin or $\beta-$ limit dextrin. The amounts of protein per lane were $60 \mu \mathrm{g}$ in the amylopectin and $90 \mu \mathrm{g}$ in the $\beta$-limit dextrin gel.

be a secondary effect and not the primary cause. It should also be mentioned that the role of $\beta$ - amylases, which were found in many cases to be extrachloroplastic (Ziegler and Beck, 1986; Lin et al., 1988), in leaf-starch metabolism, is far from clear (Ghiena et al., 1993). Caspar et al. (1989) proposed that high $\beta$ - amylase activity could be induced in reponse to accumulation of soluble sugars and this possibility must be considered in our case as well. A similar response of $\beta$ - amylase accumulation to sucrose and soluble sugars was reported in leaf petiole cuttings of sweetpotato (Nakamura et al., 1991). Huber (1984) suggested that the accumulation of soluble sugar was involved in maintenance of leaf osmotic potential in K-deficient leaves. Potassium also plays a critical role in the phloem translocation mechanism (Bhandal and Malik, 1988). The impairment of phloem transport under K deficiency may lead to the accumulation of soluble sugar in leaves. This perturbation of carbohydrate metabolism may possibly account for the reduction of Citrus fruit size under conditions of $\mathrm{K}$ deficiency (Chapman, 1968).

From a different perspective, the elevated level of invertase might have a developmental significance. In starch-storing plants, including Citrus (Schaffer et al., 1987), acid invertase activity declines to very low levels during the course of leaf development (Huber, 1989). The relatively high level of acid invertase in Kdeficient Citrus leaves may reflect a metabolically juvenile condition. In view of the presumed role of $\mathrm{Ca}$ in the delay of leaf 
senescence (Poovaiah, 1988), it might be argued that Ca deficiency enhances leaf senescence, as reflected by the accumulation of starch and the disappearance of acid invertase activity. The association of $\mathrm{Ca}$ deficiency with leaf senescence fits very well with the loss of chlorophyll, total protein, and Rubisco protein, which have been found to be characteristic of $\mathrm{Ca}$ deficiency in Citrus leaves (Lavon, 1992).

\section{Literature Cited}

Bar-Akiva, A. 1974. Nitrate estimation in citrus leaves as a means of evaluating nitrogen fertilizer requirements of citrus trees. Proc. Intl. Citricult. Congr., Murcia, Spain 1:159-164.

Beers, E.P. and S.H. Duke. 1988. Localization of $\alpha$ - amylase in the apoplast of pea (Pissum sativum L.) stems. Plant Physiol. 87:799-802.

Bhandal, I.S. and C.P. Malik. 1988. Potassium estimation uptake and its role in the physiology and metabolism of flowering plants. Intl. Rev. Cytol. 110:205-254.

Caspar, T., T.P. Lin, J. Monroe, W. Bernhard, S. Spilatro, J. Preiss, and C. Somerville. 1989. Alteredregulation of $\beta$ - amylase activity in mutants of Arabidopsis with lesions in starch metabolism. Proc. Natl. Acad. Sci. USA. 86:5830-5833.

Chapman H.D. 1968. The mineral nutrition of citrus, p. 127-289. In: W. Reuther, L.D. Batchelor, and H.J. Webber (eds.). The citrus industry. revised ed. vol. 2. Univ. of California.

Doehlert, D.C., S.H. Duke, and L. Anderson. 1982. Beta-amylases from alfalfa (Medicago sativa L.) roots. Plant Physiol. 69:1096-1102.

Embleton, T.W., H.J. Reitz, and W.W. Jones. 1973. Citrus fertilization, p. 122-181. In: W. Reuther, L.D. Batchelor, and H.J. Webber (eds.). The citrus industry. revised ed. vol. 3. Univ. of California.

Fischer, E.S. and E. Bremer. 1993. Influence of magnesium deficiency on rates of leaf expansion, starch and sucrose accumulation, and net assimilation in Phaseolus vulgaris. Physiol. Plant 89:271-276.

Ghiena, C., M. Schultz, and H. Schnabl. 1993. Starch degradation and distribution of the starch-degrading enzymes in Vicia faba leaves. Plant Physiol. 101:70-73.

Golomb, A. 1984. Calcium metabolism in citrus trees in relation to fruitpeel blemishes. PhD diss. The Hebrew Univ. of Jerusalem, Rehovot, Israel.

Goldschmidt, E.E. and A. Golomb. 1982. The carbohydrate balance of alternate bearing citrus trees and the significance of reserves for flowering and fruiting. J. Amer. Soc. Hort. Sci. 107:206-208.

Hammond, J.B.W. and K.S. Burton. 1983. Leaf starch metabolism during the growth of pepper (Capsicum annuum) plant. Plant Physiol. 73:6165 .

Hewitt, E.J. 1966. Sand and water culture methods used in the study of plant nutrition. Tech. Commun. 22, Commonwealth Bureaux of Hort. and Plantation Crops, East Malling, England.
Huber, S.C. 1984. Biocehmical basis for effects of K-deficiency on assimilate export rate and accumulation of soluble sugars in soybean leaves. Plant Physiol. 76:424-430.

Huber, S.C. 1989. Biochemical mechanism for regulation of sucrose accumulation in leaves during photosynthesis. Plant Physiol. 91:656662.

Kakefuda, G. and S.H. Duke. 1984. Electrophoretic transfer as a technique for the detection and identification of plant amylolytic enzymes in polyacrylamide gels. Plant Physiol. 75:278-280.

Kakefuda, G., S.H. Duke, and M.S. Hostak. 1986. Chloroplast and extrachloroplastic starch degrading enzymes in Pisum sativum L. Planta. 168:175-182.

Lavon, R. 1992. The effect of calcium, magnesium and potassium deficiencies on metabolism and development of citrus plants. PhD diss. The Hebrew Univ. of Jerusalem, Israel.

Lin, T.P., S.R. Spilatro, and J. Preiss. 1988. Subcellular localization and characterization of amylases in Arabidopsis leaf. Plant Physiol. 86:251259.

Nakamura, K., M. Ohto, N. Yoshida, and K. Nakamura. 1991. Sucroseinduced accumulation of $\beta$ - amylase occurs concomitant with the accumulation of starch and sporamin in leaf-petiole cuttings of sweet potato. Plant Physiol. 96:902-909.

Orion, D. and A. Frank. 1990. An electron microscopy study of cell wall lysis by Meloidogyne javanica gelatinous matrix. Rev. Nematol. 13: 105107.

Poovaiah, B.W. 1988. Calcium and senescence, p. 359-389. In: L.D. Nooden and A.C. Leopold (eds.). Senescence and aging in plants. Academic Press, New York.

Sanz, A. and J.L. Guardiola. 1988. Amylases from orange leaves. Characterization and relation to starch breakdown. Plant Physiol. (Life Sci. Adv.) 7:85-89.

Schaffer, A.A., E.E. Goldschmidt, R. Goren, and D. Galili. 1985. Fruit set and carbohydrate status in alternate and nonalternate bearing citrus cultivars. J. Amer. Soc. Hort. Sci. 110:574-578.

Schaffer, A.A., O. Sagee, E.E. Goldschmidt, and R. Goren. 1987. Invertase and sucrose synthase activity, carbohydrate status and endogenous IAA levels during citrus leaf development. Physiol. Plant. 69: 151-155. Somogy, M. 1952. Notes on sugar determination. J. Biol. Chem. 195: 19-23. Vesk, M., J.V. Possingham, and E.V. Mercer. 1966. The effects of mineral nutrients deficiencies on the structure of leaf cells of tomato, spinach and maize. Austral. J. Bot. 14:1-8.

Wall, M.E. 1939. The role of potassium in plants. I. Effect of varying amounts of potassium on nitrogenous, carbohydrate and mineral metabolism in the tomato plants. Soil Sci. 47:143-146.

Ward, G.W. 1960. Potassium in plant metabolism III. Some carbohydrate changes in the wheat seedling associated with varying rates of supply. Can. J. Plant Sci. 40:729-735.

Ziegler, P. and E. Beck. 1986. Exoamylase activity in vacuoles isolated from pea and wheat. Plant Physiol. 82: 1119-1121. 